\title{
Structural evolution of the Paleoproterozoic Rio Itapicuru granite-greenstone belt (Bahia, Brazil): the role of synkinematic plutons in the regional tectonics
}

\author{
A. Chauvet ${ }^{\mathrm{a}, *}$, F.C. Alves Da Silva ${ }^{\mathrm{b}}$, M. Faure ${ }^{\mathrm{a}, \mathrm{c}}$, C. Guerrot $^{\mathrm{d}}$ \\ ${ }^{a}$ CNRS-UMR 6530 and FR 09, Département des Sciences de la Terre, Université d'Orléans, BP 6759, \\ 45067 Orléans Cédex 2, France

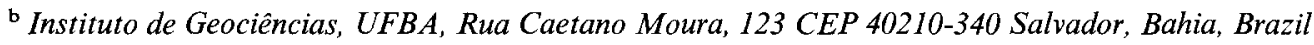 \\ ${ }^{\circ}$ Institut Universitaire de France, Paris, France \\ ' BRGM, SGN/I2G, BP 6009, 45060 Orléans Cédex 02, France
}

Received 17 December 1996; accepted 18 April 1997

\begin{abstract}
The Paleoproterozoic structural evolution of the Rio Itapicuru greenstone belt (RIGB, Bahia, Brazil) involves two tectonic events of different natures, both associated with magmatism. The first event (D1) developed in response to NW-SE shortening and was responsible for subhorizontal foliation, NW-SE trending lineation and SE-directed thrusts. D1 was coeval with the emplacement of rare $2130 \mathrm{Ma}$ granodioritic plutons. The D2 tectonic event was characterized by left-lateral strike-slip tectonics, developed on steeply dipping D1 foliation and within numerous $\mathrm{N}-\mathrm{S}$ elongated ca $2080 \mathrm{Ma}$ plutons. Quartz c-axis analysis within the granites shows that they experienced progressive leftlateral shearing from magmatic to solid-state conditions under decreasing temperatures. This fact, in addition to microstructural arguments, indicates syntectonic emplacement of these plutons. A zone of maximum deformation (the Main Shear Zone) has been identified in the centre of the RIGB on the basis of strain measurements. A tectonic model in which D1 thrusting event initiated basin closure before being replaced by D2 strike-slip motion is proposed. The Main Shear Zone corresponds successively to the main thrust zone and the main wrench fault during Dl and D2 events, respectively. Such a switch from orogen-normal thrusts to orogen-parallel transcurrent movements may represent a common progression during evolution of mountain belts in order to accommodate excess crustal thickness. However, because low-grade metamorphism and low intensity of the deformation demonstrate that excess crustal thickness was not attained, it is argued that granite emplacement and ascent played a significant role in triggering strike-slip tectonics in the RIGB. (C) 1997 Elsevier Science B.V.
\end{abstract}

Keywords: Brazil; Greenstone belts; Paleoproterozoic ; Quartz fabrics; Strain; Syntectonic granite

\footnotetext{
* Corresponding author. Tel: 33-2-38-41-72-26; e-mail: alain.chauvet@univ-orleans.fr
} 


\section{Introduction}

The association of large volumes of granitoids and low grade supracrustal rocks in Paleoproterozoic and Archaean granite-greenstone terranes is frequently a matter of discussion, particularly the tectonic setting in which their 'dome-and-keel' geometry formed (e.g. Platt, 1980; Shackleton, 1986; Marshak et al., 1992; Jelsma et al., 1993). These terranes also provide good locations for the study of the interactions that may exist between regional and pluton-related tectonics (e.g. Brun and Pons, 1981; Hutton, 1988; Paterson et al., 1989; Guglielmo, 1993; Pons et al., 1995). Since collisional tectonics seems demonstrated within some Precambrian terranes like Canadian or South African belts (e.g. Lucas, 1989; Hanmer et al., 1992; de Wit et al., 1992), the Paleoproterozoic domains of West Africa and South America have been interpreted to be a consequence of interference folding, pluton ballooning or combination of both processes (e.g. Marshak and Alkmim, 1989; Bertrand and Jardim de Sá, 1990; Ledru et al., 1991; Teixeira and Figueiredo, 1991; Chauvet et al., 1994).

This paper presents a detailed analysis of the Paleoproterozoic Rio Itapicuru greenstone belt (RIGB, Bahia state, NE Brazil) using structural and kinematic features, quartz $\langle c\rangle$ axis fabrics, and finite strain. The Paleoproterozoic structural evolution of the area, even if initial stages involved thrusting, was dominated by wrench faulting and contemporaneous plutonism. We present a tectonic model in which the switch from contractional to strike-slip tectonic regimes was assisted by the ascent and emplacement of granodioritic plutons.

\section{Geological setting}

The RIGB, located within the NE border of the São Francisco Craton (Fig. 1a), is a N-S elongate belt ca $100 \mathrm{~km}$ long and $60 \mathrm{~km}$ wide (Fig. 1b). It represents one of the numerous granite-greenstone belts that make up the craton, in addition to Archaean granulitic complexes (Gavião, Jequié and Santa Luz domains), Archaean/Paleoproterozoic gneisses ('Salvador-Curaçá' and
'Atlantic Coast' mobile belts) and postPaleoproterozoic deposits (Fig. 1a). The RIGB has been affected by the Paleoproterozoic Transamazonian orogeny which developed between $2209 \mathrm{Ga}$ (age of the supracrustal protoliths) and $1800 \mathrm{Ga}$ (age of the latest granitic intrusions near Santa Luz) (Brito Neves et al., 1980; Gaál et al., 1987; Silva, 1992; Silva and Vidal, 1992). The supracrustal pile, estimated to be $9.5 \mathrm{~km}$ thick (Davison et al., 1988) includes from base to top:

(1) $5 \mathrm{~km}$ thick E-MORB sea-floor tholeiitic basalts (Silva, 1992);

(2) $3.5 \mathrm{~km}$ thick andesitic and rhyodacitic lavas, similar to those of modern active continental margins (Silva, 1992); and

(3) $1 \mathrm{~km}$ thick arkose and conglomerate (Kishida and Riccio, 1980) (Fig. 2a).

Silva (1987) suggested a back-arc environment for the deposition of this sequence on the basis of geochemical and petrological constraints.

\subsection{The Transamazonian granitoids and Archaean basement gneisses}

Field study and aerial photograph analysis allowed mapping of the granitic bodies represented in Fig. 1b. The granodioritic intrusions of calcalkaline affinity (Silva, 1987) were emplaced ca $2.0 \mathrm{Ga}$ (Gaál et al., 1987). We distinguish two domains in the region (Fig. 1b). In the northern domain, the Ambrósio, Pedra Alta and Poço Grande plutons exhibit a N-S elongate shape that is less pronounced towards the west (i.e. the Nordestina massif, Fig. 1b). They display a welldeveloped foliation in their granodioritic/tonalitic margins whereas granitic/granodioritic cores are more isotropic (Matos and Davison, 1987; Silva, 1987). In the southern domain, the Barrocas complex has E-W trending long axis and internal structure, parallel with the orientation of the structural elements in the host rocks. Recent ${ }^{207} \mathrm{~Pb} /{ }^{206} \mathrm{~Pb}$ zircon ages suggest that the Barrocas pluton is older (crystallization age of $2127 \pm 5 \mathrm{Ma}$ ) than the $\mathrm{N}-\mathrm{S}$ trending granites (crystallization age of $2100 \pm 10 \mathrm{Ma}$ ) (Alves da Silva, 1994; Chauvet et al., 1997). U-Pb zircon age of $2.930 \pm 32 \mathrm{Ga}$ for a xenolith of banded gneisses found within the 




Fig. 1. (a) Geological map of the Bahia state, modified from Mascarenhas (1976) and Sabaté et al. (1990). (b) Simplified structural map of the RIGB with location of Figs. 2 and 4. Granite names and main gold mines are indicated. (c) Stereographic diagrams (Schmidt, lower hemisphere stereonets) of foliation planes and lineations within the N and SE domains of the RIGB. 
W

$\mathbf{E}$
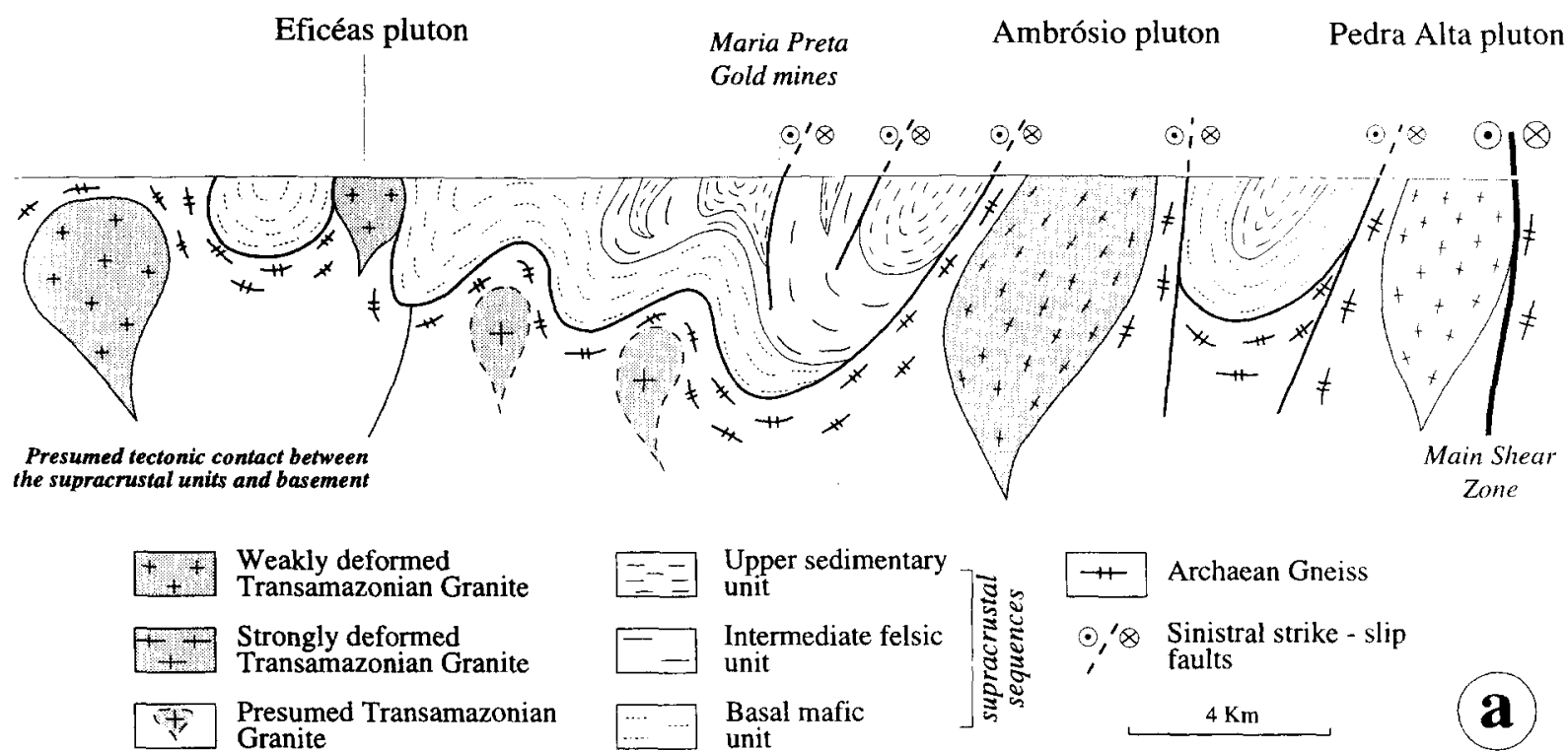

\section{Barrocas pluton}

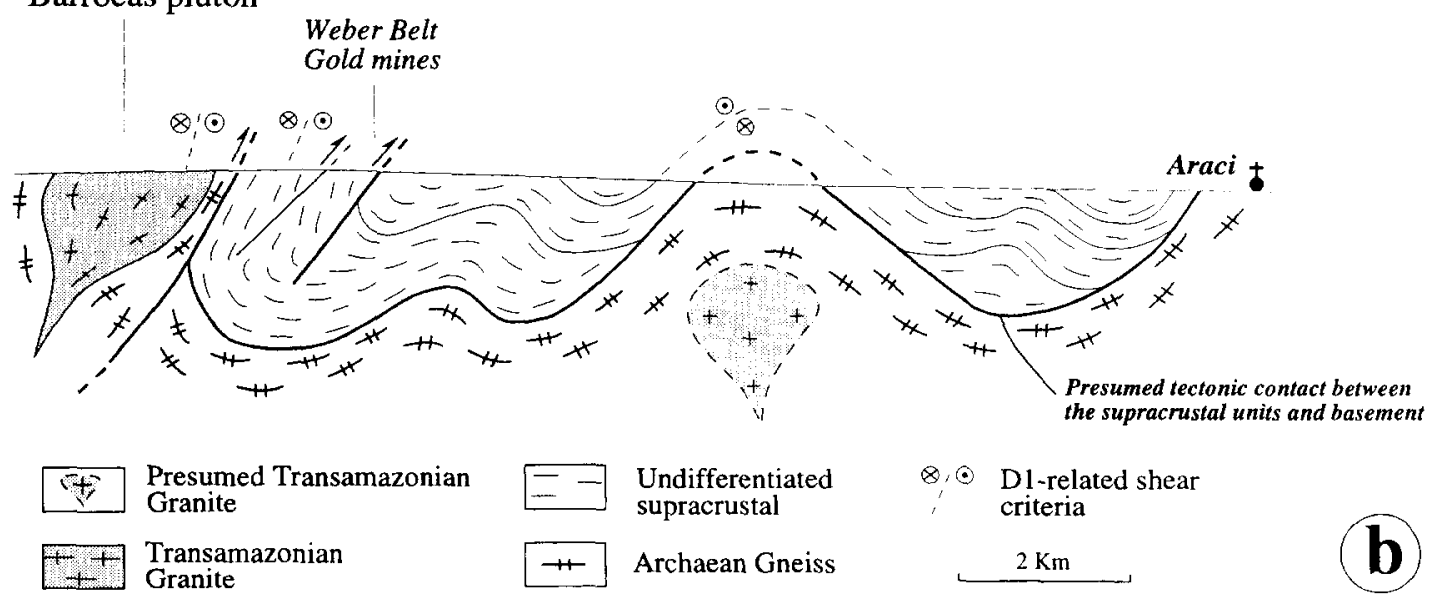

Fig. 2. Detailed E-W and NE-SW cross-sections showing the megastructures of the RIGB. Precise location on Fig. 1b. The shape of plutons at depth is extrapolated. For each cross section, vertical and horizontal scales are equal.

highly deformed border of the Ambrósio pluton supports the existence of an Archaean sialic basement around the granites and below the supracrustal units (Gaál et al., 1987; Davison et al., 1988).
Other outcrops of Archaean basement are found in the vicinity of Santa Luz where a NW-SE trending succession of granulitic gneiss and migmatite is exposed (Lamarck Argolo et al., 1994). 


\subsection{Previous structural data}

Existing models conclude that the architecture of the northern RIGB results from an E-W contraction resulting in large-scale folding and $\mathrm{N}-\mathrm{S}$ elongated plutons (Davison et al., 1988; Lamarck Argolo et al., 1994). The relationships with the E-W trending structures in the southern area was not addressed in these interpretations. Other authors propose a polyphase evolution to account for the complex structure of the southern domain (Teixeira, 1985; Reinhardt and Davison, 1990; Teixeira et al., 1990). The first attempt to relate the northern ( $\mathrm{N}-\mathrm{S}$ trending) and southern (E-W trending) domains attributed the southern deflection to a late megascopic fold (Alves da Silva and Matos, 1991). In this model, the development of two successive events, a top-to-the east thrusting and a sinistral shearing, respectively, is suggested, but no clear evidence for the thrusting was provided.

\subsection{Metamorphism}

Three distinct metamorphic events were recognized within the supracrustal rocks of the central RIGB (Silva, 1987). The first one, related to oceanic sea-floor hydrothermal activity, consisted of spilitization of the volcanic pile (pressure of ca $0.2 \mathrm{kbar}$ for maximum temperature of $400^{\circ} \mathrm{C}$ ). The second event developed under greenschist $\left(350^{\circ} \mathrm{C}\right.$ at $2 \mathrm{kbar})$ to amphibolite $\left(650^{\circ} \mathrm{C}\right.$ at $\left.4 \mathrm{kbar}\right)$ facies conditions and was coeval with the emplacement of main granitic plutons. Amphibolite facies only occur within the contact aureole around the intrusions. A later, and minor, third event seems related to contact metamorphism around late-tectonic bodies.

\section{Structural analysis}

Two cross-sections drawn across the RIGB illustrate the importance of large-scale synforms and antiforms in the regional structure (Kishida and Riccio, 1980; Davison et al., 1988) (Fig. 2). These are open folds with subvertical axial planes and sub-horizontal axes that trend $\mathrm{N}-\mathrm{S}$ in the northern RIGB and E-W to NW-SE in the southern domain (Fig. 1b). These folds deform the main foliation developed throughout both metasediments and granite-gneissic rocks. Within northern area, foliation is high-dipping and $\mathrm{N}-\mathrm{S}$ trending, parallel to the large-scale fold axes (Fig. 1c). Its orientation only changes within fold hinges, thus explaining the well defined diagram. A sub-horizontal stretching lineation assumed to result from the D2 tectonic event occur along the foliation planes (Fig. 1c). The southern area contains a more complex pattern that we interpret to be the result of the combination of two tectonic events, D1 and D2 (Fig. 1c).

\subsection{Deformation within the supracrustal units}

\subsubsection{D2 tectonic event}

Because D2 structures are the best expressed ones within the RIGB, they will be presented first. This event developed sub-horizontal stretching lineation (Fig. 1c) and sinistral shearing along N-S trending sub-vertical foliation planes. Quartz rods and biotite/chlorite streaks are the main elements defining the stretching lineation. Common shear criteria include S/C fabrics and asymmetric pressure shadows (Fig. 3a-c). Sinistral shear criteria related to the D2 event affect both flanks of the large-scale synforms and antiforms thus indicating that they were formed after or during these structures (Fig. 2a). Along the Rio Itapicuru section, pillow-lavas of the basal unit, located to the west, are unaffected by the D2 deformation. An eastward increase of deformation is indicated by the development of more pervasive and homogeneous foliations. Close to the Ambrósio pluton, mainly localized along the lithological contact, well-developed foliation and lineation define sinistral shear zones. The largest gold mines of the northern area are located along these shear zones (i.e. Maria Preta Gold Mines, Figs. 1b and 2a). D2-related structures were associated with mineral assemblage composed by quartz, biotite, white mica, chlorite and more scarcely garnet, andalusite and sillimanite. They define metamorphic conditions close to the upper greenschist/amphibolite facies, in agreement with previous works that demonstrate that the area was affected by a regional metamor- 

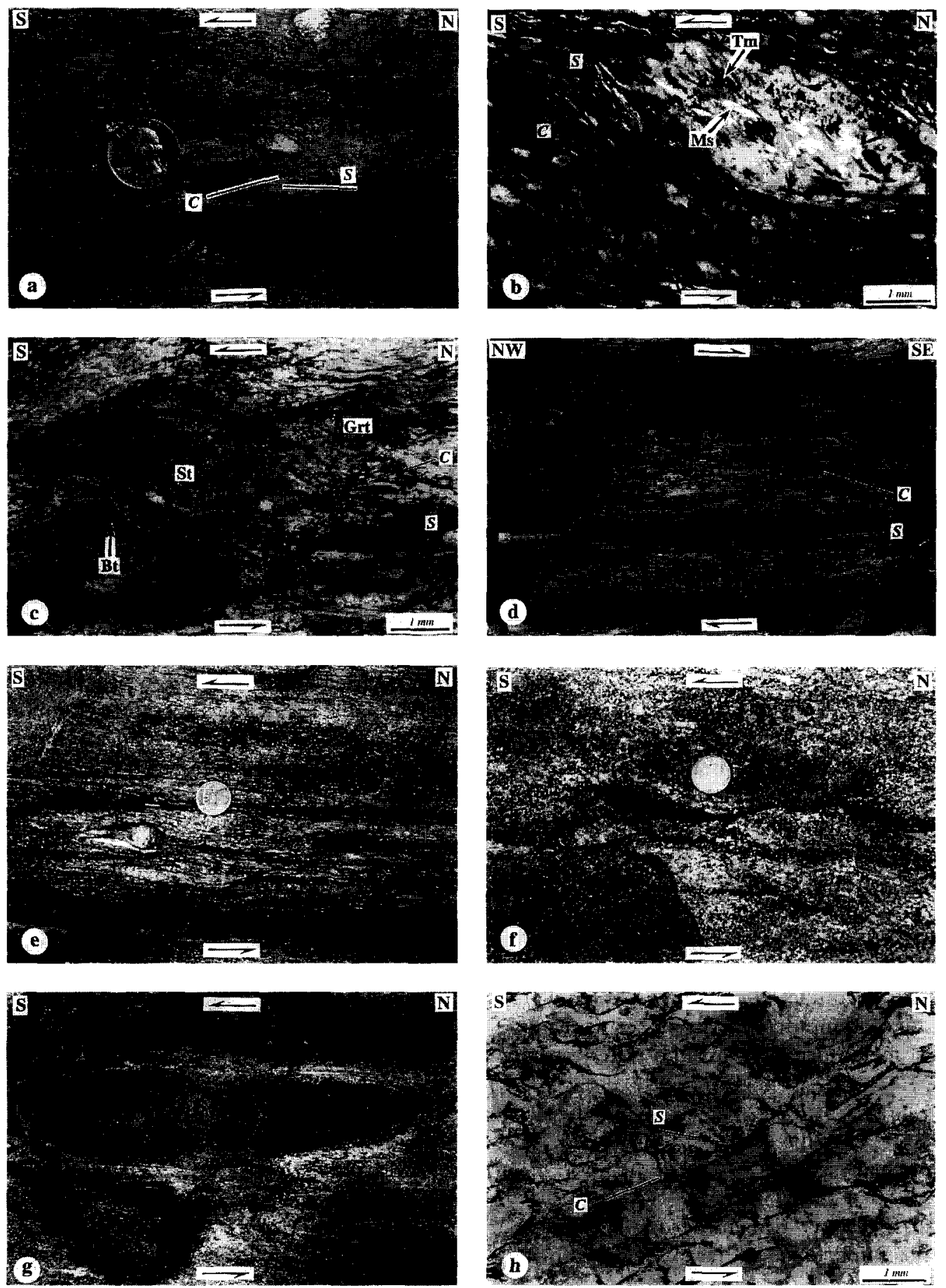
phism characterized by $P-T$ conditions bracketed between $350^{\circ} \mathrm{C}-2 \mathrm{kbar}$ and $650^{\circ} \mathrm{C}-4 \mathrm{kbar}$ (M2 event, Silva, 1987).

\subsubsection{DI tectonic event}

Structures related to D1 tectonic event are wellpreserved within the southern domain of the RIGB. In this area foliation trends $E-W$ to NW-SE. NW-SE trending subhorizontal lineation is expressed by oriented micaceous aggregates on foliation. Both dextral and sinistral shear senses occur on steeper foliation planes (Figs. 1c and 4). The fact that both sinistral and dextral criteria occurred on $\mathrm{E}-\mathrm{W}$ trending foliations means that these structures are not the conjugate of $\mathrm{N}-\mathrm{S}$ trending D2 sinistral shear zones. Large-scale folds with $\mathrm{E}-\mathrm{W}$ oriented axes have been recognized within this area (Fig. 4). Sinistral criteria are found within south-dipping limbs while dextral ones are observed in north-dipping and inverted southdipping ones (Figs. $2 b$ and 4 ). Such a geometry demonstrates that shear criteria are related to an older tectonic event (D1) and folded by D2 or latter structures. Because axes were subparallel with the lineation direction, folds did not strongly change the lineation's initial orientation. Data collected along the NE-SW trending road from Araci to Salgadalia confirm this interpretation (Fig. 5a, see Fig. 4 for the location). To the east, foliation dips $60^{\circ} \mathrm{SW}$ and contains top-to-SE shear bands (Fig. 3d). South-westwards, the foliation direction turns progressively to an $\mathrm{E}-\mathrm{W}$ direction and becomes reoriented by $\mathrm{N}-\mathrm{S}$ trending sinistral shear zones. These zones become more intense westward until the appearance of kilometre-scale intrusions of quartz-porphyric rocks, which contain a pervasive $\mathrm{N}-\mathrm{S}$ trending foliation and nearhorizontal stretching lineation. The intrusion has a N-S trending ellipsoidal shape (Fig. 4) and shear criteria such as asymmetric pressure shadows around quartz eyes indicate everywhere a sinistral ductile shearing (Fig. 3e). Based on geometrical arguments, these sinistral shear zones, which overprint the earlier top-to-the SE shears, are attributed to the D2 tectonics. Another outcrop, found in the vicinity of the Salgadalia pluton, shows the same sequence of events (Fig. 5c, see Fig. 4 for location). It consists of a $\mathrm{D} 2$ foliated pegmatite body oriented $040^{\circ}$ which intrudes and deforms the D1 foliation oriented $120^{\circ}$. The D2-related sinistral shear zones are only found within and in the vicinity of the pegmatite.

The D1 tectonic event is characterized by topto-E-SE shearing assumed to have resulted in development of shallowly dipping foliation (Fig. 6a). Close to the Salgadalia pluton, top-toE-SE shear criteria could be attributed to this event (Fig. 4). In the Archaean basement near Santa-Luz (Fig. 1b), gneisses and amphibolites also bear $120^{\circ}$ trending stretching lineation. Since top-to-SE shearing is observed in these rocks, we suggest that Archaean could be overthrusted over the Paleoproterozoic. This deformation is geometrically and kinematically compatible with the D1 event defined in the supracrustal units. Subsequently, D1 structures were affected by largescale upright folds, which account for the inversion of shear criteria observed along the AraciSalgadalia profile (Fig. 6b). On south-dipping foliation planes, shearing is sinistral whereas it is dextral on north-dipping ones. Within the Weber belt, the foliation is overturned and dextral shear criteria occur on south-dipping foliation (Fig. 6b).

Metamorphic conditions related to the D1 event are difficult to determine because of the strong overprinting by D2. However, the occurrence of

\footnotetext{
Fig. 3. Photographs of D1 and D2 structures within supracrustal and magmatic rocks. Foliation is vertical within all photographs except (d). (a) D2 asymmetric pressure shadows and shear planes in agglomerate layers along the Itapicuru river section. S, schistosity; $\mathrm{C}$, c-plane. (b) D2 shear plane deforming a cordierite porphyroblast crystallized during the syn-D1 metamorphism; Ms, muscovite; Tm, tourmaline; S, schistosity; C, c-plane. (c) D2-related shear planes superimposed on syn-D1 biotite (Bt), staurolite (St) and garnet (Grt). S, schistosity; C, c-plane. (d) Shear bands showing a top-to-the-SE-motion during D1 event in the sedimentary unit of the SE domain of the RIGB. S, schistosity; C, c-plane. (e) D2 left-lateral porphyroclast system within a NS foliated quartz-porphyry body, located in the SE part of the RIGB. (f) N-S trending sigmoidal schlieren, indicating D2 left-lateral shearing in Pedra Alta pluton. (g) Elliptic tonalitic enclave with deflected internal foliation consistent with D2 left-lateral shearing, Pedra Alta pluton (see text for explanation). (h) Left-lateral shear bands within the eastern margin of the Pedra Alta pluton. S, schistosity; C, c-plane.
} 


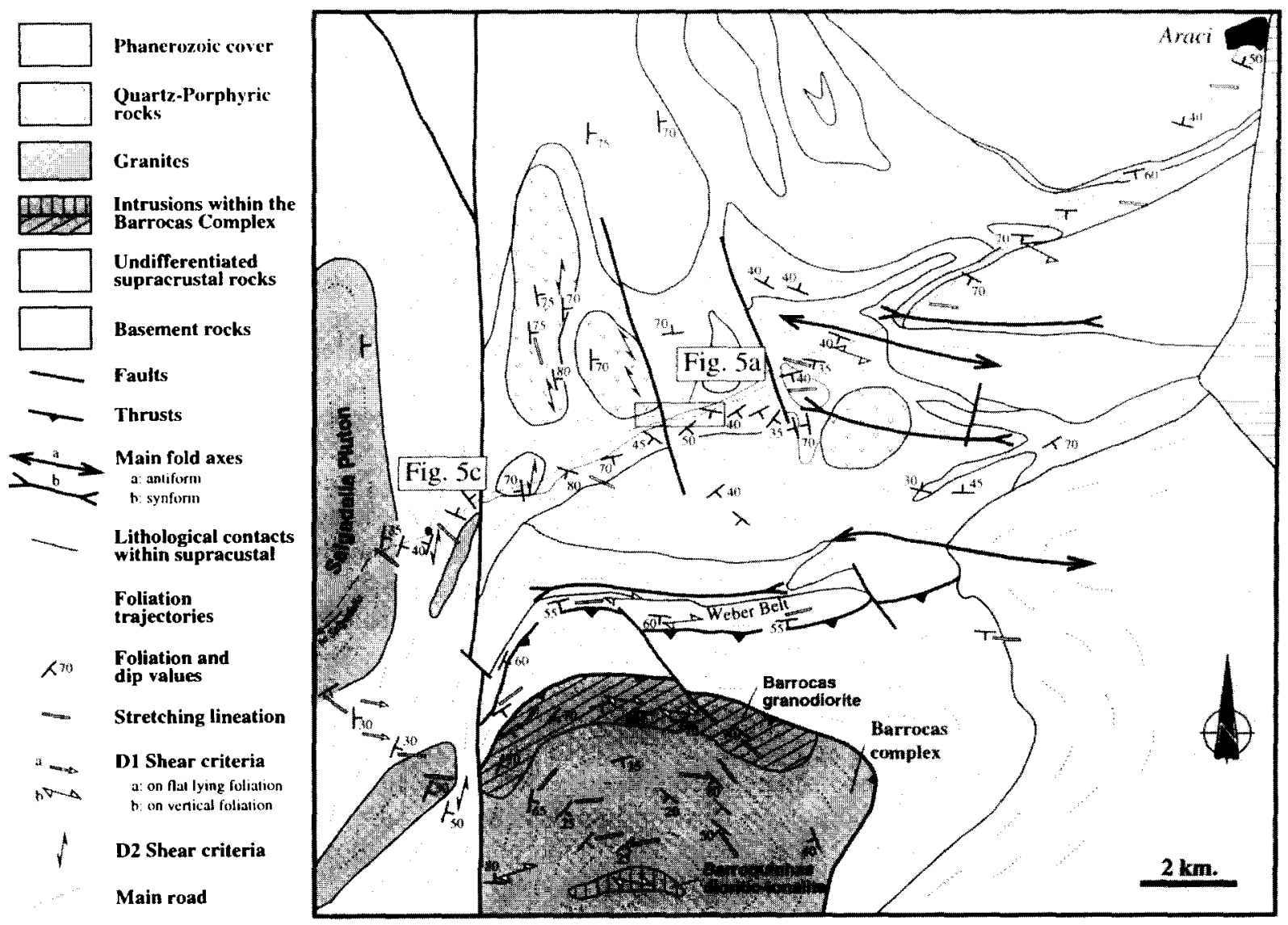

Fig. 4. Detailed structural map of the SE domain of the RIGB. Note the coexistence of EW oriented dextral and sinistral shear criteria.

early cordierite, staurolite, biotite, garnet, white mica and quartz is observed within samples coming from the southern part of the studied area where D2 effects are less marked (Fig. 3b and c). These minerals could indicate that D1 tectonics, also developed under greenschist facies conditions, probably D2, but the lack of better mineralogical constraint does not allow us to be more certain about this.

\subsection{Deformation within the granitoids}

Within granodioritic plutons, biotite and feldspar preferred orientations define a foliation that contains a nearly-horizontal mineral lineation marked by: elongated feldspar and quartz grains; and aligned trains of biotite (Fig. 7). Both foliation and lineation are attributed to the D2 tectonic event. The foliation defines a concentric shape (Fig. 7). Within the Ambrósio pluton, foliation is less steep at the northern and southern extremities and dips ca $45^{\circ} \mathrm{W}$ along the western border (Fig. 7b). In the Pedra Alta and Poço Grande bodies, foliation is vertical everywhere and, because pluton shapes are so elongate, the concentric geometry is less clear (Fig. 7c). Along pluton margins, foliation is due either to mineralogical banding or mylonitization whereas in the pluton interior, planar and linear elements are less marked and magmatic features such as schlieren are preserved (Fig. 3f).

\subsubsection{Synkinematic character}

Shear criteria, observed in sections normal to the foliation and parallel to the lineation ( $\mathrm{XZ}$ 



Fig. 5. Relationships between D1 and D2 events. (a) Outcrop succession along the Araci/Salgadalia road (location on Fig. 4). (b) Interpretation (see text for explanation). (c) Syn-D2 pegmatite and superposition of D2 foliation onto D1 one close to the Salgadalia pluton (location on Fig. 4).

sections) only occur within the Ambrósio, Pedra Alta, Poço Grande and Salgadalia granites. Their nature changes with respect to their location (core or margin) and the granitoid lithology.
Unambiguous sense of shearing is difficult to determine within the Ambrósio and Salgadalia plutons in which dextral, sinistral and/or undefined criteria occur in similar proportion. In contrast, the Poço 


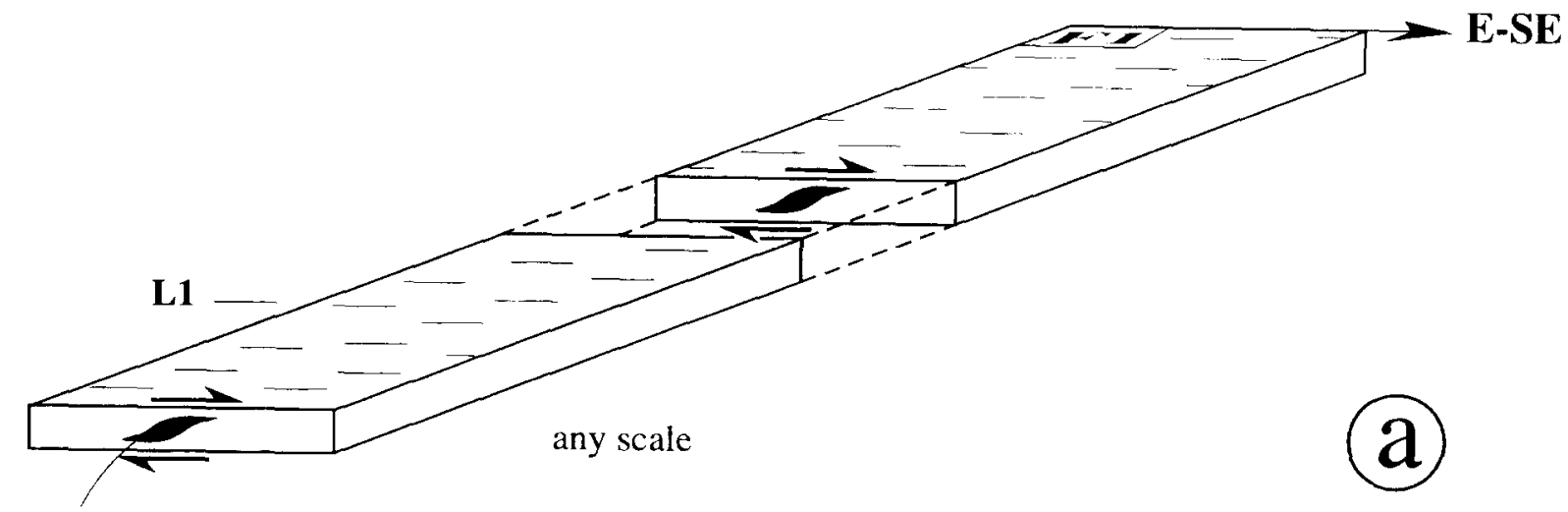

DI Top-to-the SE

shear criteria

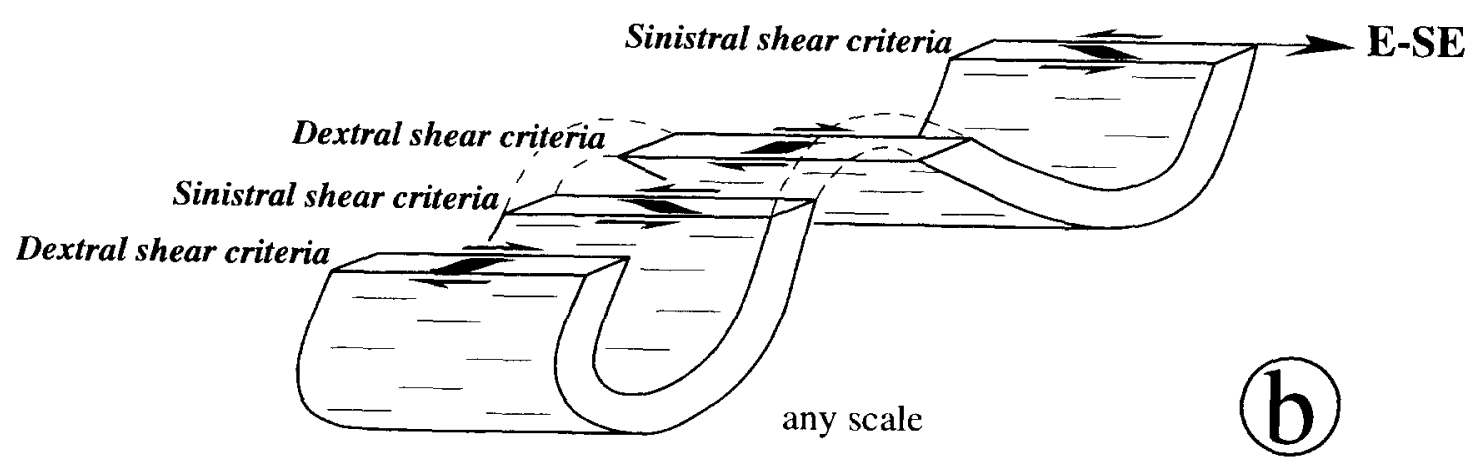

Fig. 6. Schematic diagram illustrating the geometry of D1 top-to-the SE shear criteria within the southern domain of the RIGB. (a) Initial stage and development of SE-verging shear criteria and subhorizontal foliation. (b) Folding of these shear criteria by $\mathrm{E}$-W trending folds. Shear criteria are sinistral in south-dipping foliation planes and dextral in north-dipping and overturned southdipping ones.

Grande granite is conspicuously affected by the D2 deformation which is characterized by pervasive left-lateral S/C planes. Shear criteria within the Pedra Alta pluton also indicate sinistral shearing, illustrated by pressure-shadow asymmetries, sigmoidal feldspars and, more rarely, S/C planes (Fig. 3h). Numerous ellipsoidal tonalitic enclaves contain an internal foliation with a sigmoidal pattern consistent with a sinistral deformation (Fig. 3g). One can question if these structures were caused by later solid-state deformation or created during the magmatic stage. Because similar geometry has been observed for a few enclaves, we suggest as the most likely interpretation that mafic rocks and surrounding granite are co-magmatic and both affected by the syn- magmatic D2 deformation. It is worth noting that schlieren asymmetry (Fig. 3f) indicates the same sense of shearing as the sigmoidal tonalitic enclaves.

The widespread occurrence of pervasive ductile shear bands is diagnostic of retrograde deformation histories typical of syntectonic plutons (Gapais, 1989). Thus, pervasive shear bands developed within the Poço Grande granite favour the occurrence of syn-magmatic deformation. These observations, supported by the existence of synkinematic andalusite and garnet porphyroblasts within the thermal aureole of the Ambrósio pluton (Matos and Davison, 1987), argue for a syn-D2 emplacement of the granites.

The Nordestina and Eficéas plutons have a 


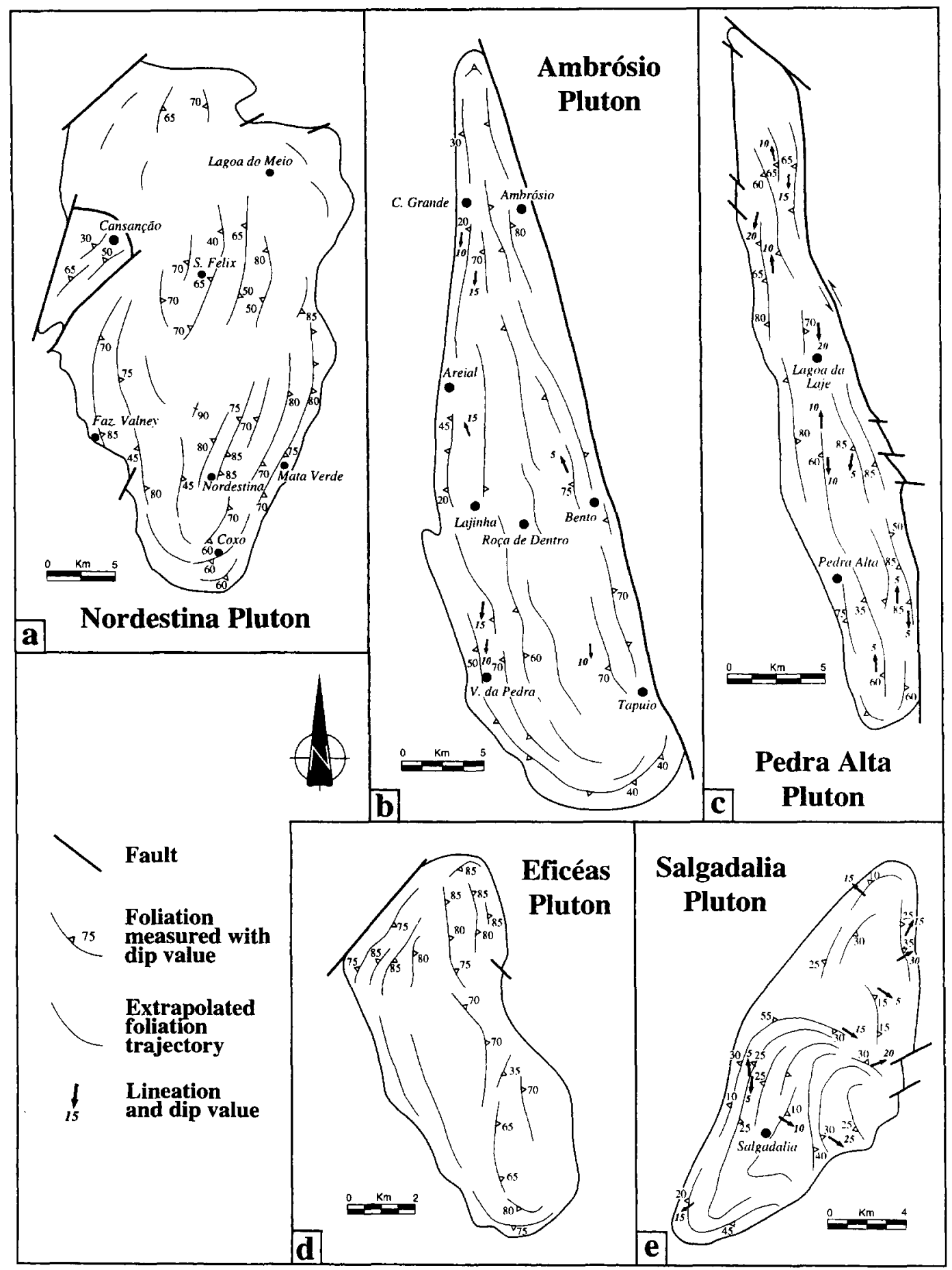

Fig. 7. Detailed structural map of the (a) Nordestina, (b) Ambrósio, (c) Pedra Alta, (d) Eficéas and (e) Salgadalia plutons. 
slightly elongate shape (axial ratio of ca 2; Fig. 7a and d) and preserved magmatic structures. No shear criteria related to D2 have been observed in the plutons. The Ambrósio and Salgadalia plutons exhibit an ellipsoidal shape (axial ratio of ca 4.5; Fig. $7 \mathrm{~b}$ and e) and contain D2 fabrics but the sense of shearing is difficult to determine. The Pedra Alta and Poço Grande plutons, located more to the east, are more elongated (axial ratio of ca 7; Fig. 7c) and have well developed D2 structures that yield an unambiguous sinistral sense of shear. It is now widely believed in the case of strike-sliprelated syntectonic granitoids that the elongated shape of a pluton results from the interplay between regional tectonic-related and plutonrelated forces (e.g. Brun and Pons, 1981; Guglielmo, 1993). Thus, it seems that D2 deformation recorded by the syn-kinematic intrusions increases in intensity from west to east up to a narrow zone that we name the 'Main Shear Zone' (MSZ; Fig. 1b). The most elongated plutons are those which exhibit clear sinistral shear criteria. These are located close to the MSZ. It is worth noting that distribution of D2 fabrics within the supracrustal units also shows an increasing gradient from west to east (see above).

Ductile shear zones from one decimetre to one metre in size occur within highly deformed granitic margins of the Ambrósio, Pedra Alta and Salgadalia plutons. Since both sinistral and dextral shear zones are equally found with same length and a constant angle between them ( $\mathrm{ca} 120^{\circ}$ ), they are considered conjugate. Bisecting the obtuse angle between dextral and sinistral shear zones, the axis of maximum shortening is close to the normal of the main foliation. These structures may have developed during the late stage of the granite emplacement by deformation of the consolidated but still ductile outer part of the pluton in response to magma injection in the centre (Ramsay, 1989; Pons et al., 1995).

\subsubsection{The Barrocas complex}

In the extreme south of the RIGB, an orthogneissic massif called the 'Barrocas complex' differs from other plutons because: it doesn't exhibit a $\mathrm{N}-\mathrm{S}$ elongate shape; and it occurs within a domain where regional foliation is mainly oriented $\mathrm{E}-\mathrm{W}$
(Fig. 1b). Within this complex, two distinct intrusions have been recognized (Fig. 4). An E-W trending porphyritic granodiorite forms the northern part of the Barrocas complex whereas a small dioritic-tonalitic body, the Barroquinhas pluton, occurs in the south. In the Barrocas complex, foliation presents a concentric pattern and lineation is horizontal with a mean $\mathrm{E}-\mathrm{W}$ orientation (Fig. 4). Shear bands and asymmetric feldspar porphyroclast systems occur within the entire complex, but shear criteria are best developed in the northern granodiorite where margins are mylonitized over several metres. Kinematic indicators define a dextral sense of shearing (Fig. 8). As for the $\mathrm{N}-\mathrm{S}$ trending Poço Grande intrusion, the occurrence of pervasive grain-scale shear bands within intrusive rocks, diagnostic of retrograde history and interpreted to develop within syntectonic plutons, provide reliable indicators of syntectonic emplacement for the Barrocas pluton (Gapais, 1989).

The dextral shear criteria within the Barrocas complex were first interpreted as D2 shearing conjugate to the $\mathrm{N}-\mathrm{S}$ sinistral ones (Alves da Silva et al., 1993). In such a case, the Barrocas pluton, emplaced within the southern domain, is contemporaneous with the $\mathrm{N}-\mathrm{S}$ trending plutons. However, the overprinting of Dl-related shear criteria by D2-related one has been demonstrated within the supracrustal succession of this domain (see above and Fig. 5). The E-W trending shear criteria and particularly dextral ones are considered to be generated during D1 thrust event and later overturned during D2 (Fig. 6). A similar interpretation is applied to the pervasive dextral shearing that affects the northern Barrocas granodiorite. This latter is thus assumed, because of its inferred syntectonic character, to be contemporaneous with $\mathrm{D} 1$ tectonics. Monozircon ${ }^{207} \mathrm{~Pb} /{ }^{206} \mathrm{~Pb}$ age of $2127 \pm 5 \mathrm{Ma}$ obtained on this granite and representative of the crystallization age confirms this interpretation (Alves da Silva, 1994; Chauvet et al., 1997). Within error bars, this age is slightly older than the crystallization age of the D2-related granite $(2100 \pm 10 \mathrm{Ma}$ for the Nordestina pluton).

\subsubsection{Mode of emplacement}

According to the structural criteria used to identify diapiric structures (England, 1990; Jelsma 


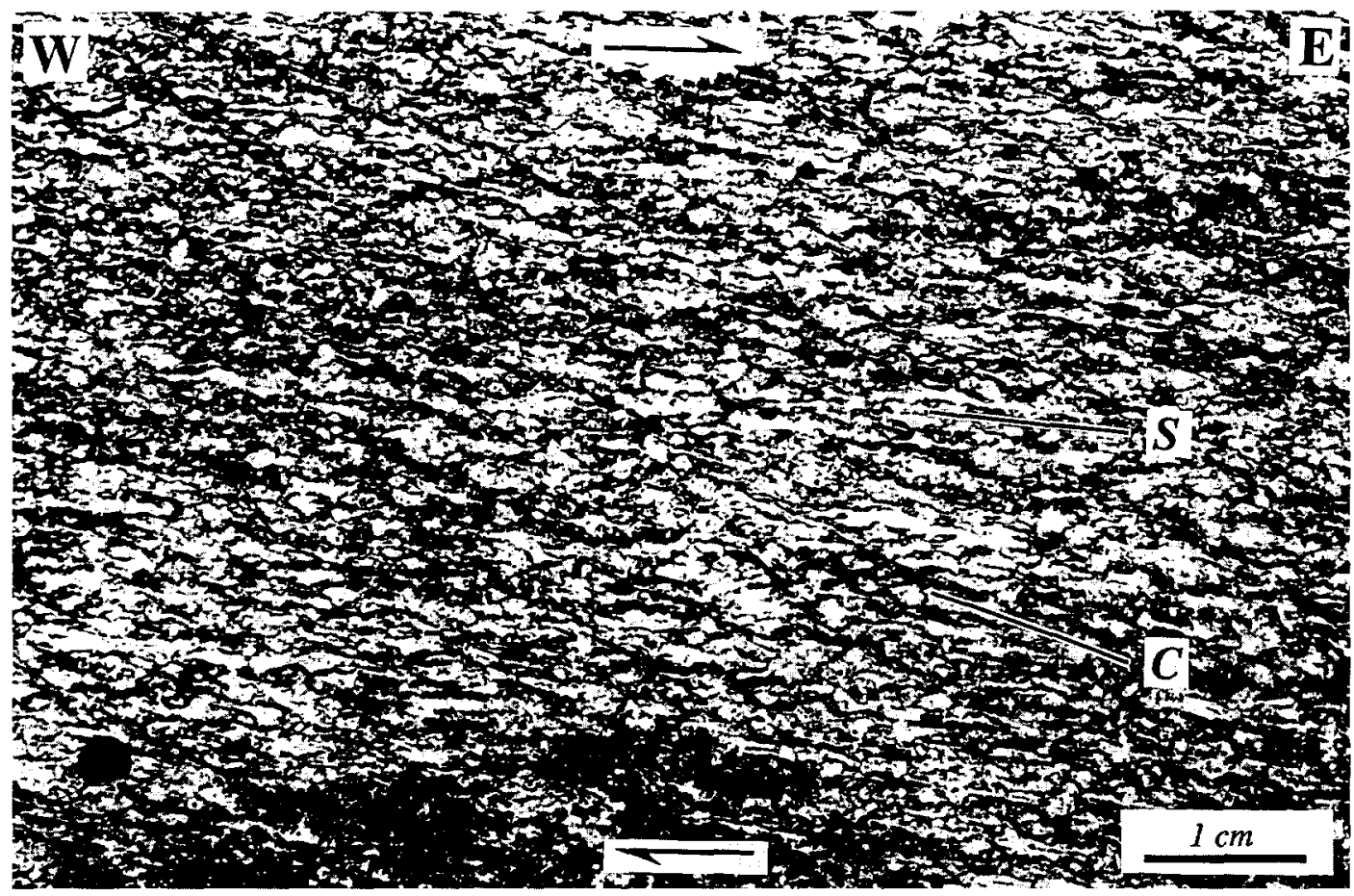

Fig. 8. Pervasive dextral S/C structure indicating D1 dextral shearing, northern margin of the Barrocas pluton. S, schistosity; C, c-plane.

et al., 1993), the parallel foliation in granite and surrounding rocks, the development of synforms within host rocks close to the intrusions (rim synclines) similar to those developed during analogue experiments (cf Dixon, 1975; Ramberg, 1981), the increase of strain intensity towards the contact, the size of the Pedra Alta, Ambrósio and Nordestina plutons (ca $10 \mathrm{~km}$ large and $20-30 \mathrm{~km}$ long) and the location of the intrusions within the core of the antiforms could be consistent with an inferred diapiric emplacement of plutons. However, taking into account the controversy concerning the process of diapiric pluton ascent (e.g. Clemens and Mawer, 1992), this interpretation still remains hypothetical. At this point, we are confident about the syntectonic character of the granites whatever the mode of emplacement (diapirism or injection and lateral expansion).

\section{Quartz c-axis fabrics}

We analysed quartz c-axis preferred orientation in both granitic rocks and quartz-rich supracrustal rocks in order to estimate the conditions of deformation during each tectonic event and to determine deformation processes within the granites. $\mathrm{C}$-axis preferred orientation was measured in $\mathrm{XZ}$ sections using a conventional Universal Stage. The results are presented in Fig. 9 and the sample locations are shown in Fig. 10.

\subsection{Quartz texture within supracrustal rocks}

Quartz c-axis distributions from two samples with $\mathrm{E}-\mathrm{W}$ trending foliation and lineation, collected within the SE domain display asymmetric skeleton patterns that confirm the D1-related topto-the-SE sense of shear (Fig. 9a). Main maxima are located on the edge of the diagrams and close to the Z-axis, whereas poorly defined secondary maxima occur close to $\mathrm{Y}$-axis. This indicates that deformation occurred by basal and prism $\langle a\rangle$ glide systems, under moderate temperature conditions (upper greenschist to lower amphibolite facies) (Nicolas and Poirier, 1976; Law, 1987). Sample Q1, located close to the MSZ, exhibits a 


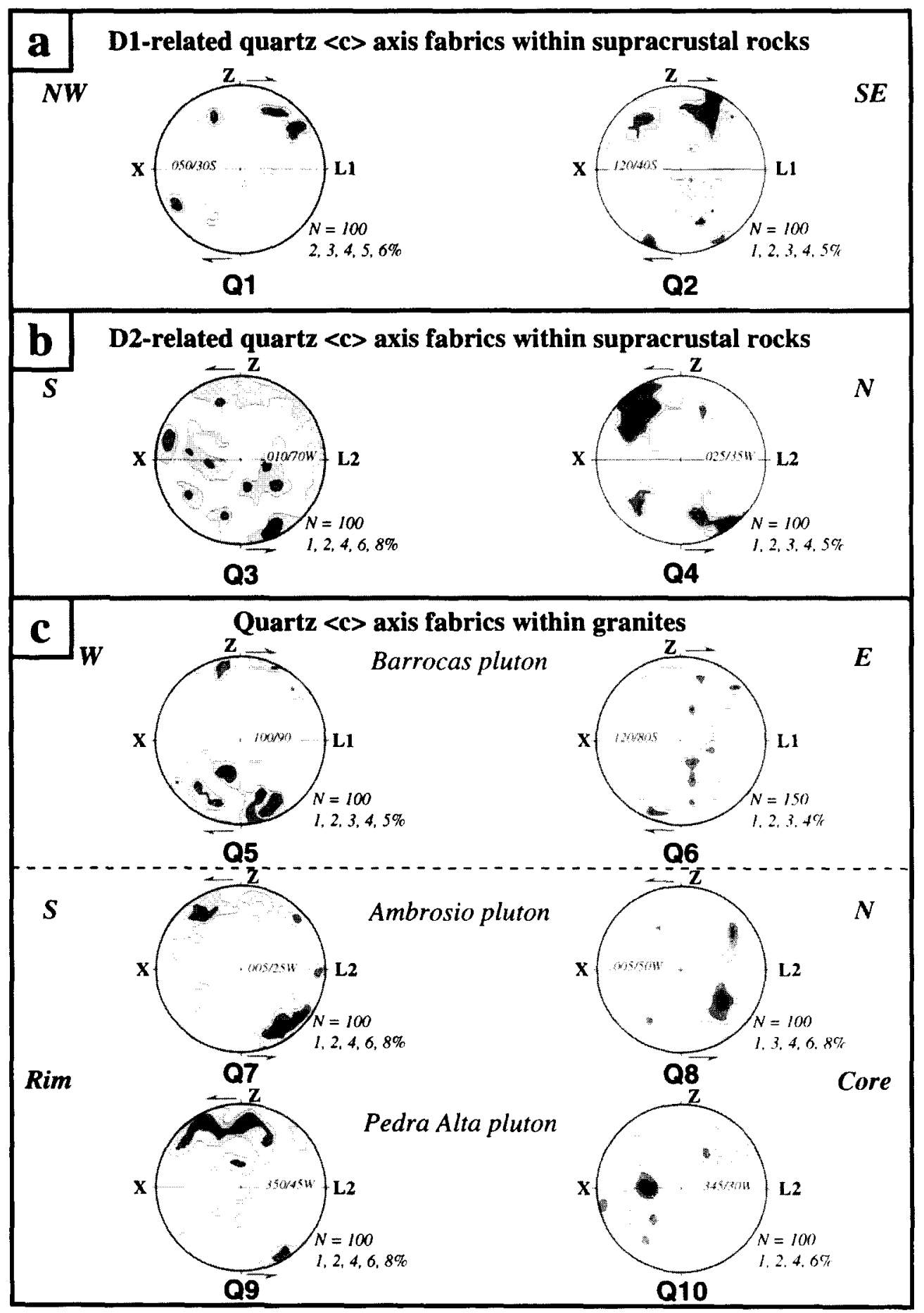

Fig. 9. Quartz $\langle c\rangle$ axis preferred orientation within quartz-rich lithologies of the RIGB. Diagrams are Schmidt, lower hemisphere stereonets. Orientation and dip of the foliation are indicated along the equator line of each diagram; lineation is sub-horizontal for each sample. Sample location is shown in Fig. 10. (a) Quartz fabrics within supracrustal samples of the southern domain, representative of D1 tectonic event. (b) Quartz fabrics within supracrustal samples of the northern domain affected by D2 tectonic event. (c) Quartz fabrics within granitic rocks (see text for explanation). 
mosaic-like recrystallization texture. For sample Q2, collected eastward, recrystallization appears less complete and relicts of large quartz grains can be observed. This variation could be correlated to a decrease of the temperature during D1 tectonics along a transverse from the MSZ area (sample Q1) toward the east (sample Q2).

In the $\mathrm{N}-\mathrm{S}$ trending domain of the RIGB, quartz aggregates consist of dynamically recrystallized grains which are elongated oblique to the foliation. C-axis diagram asymmetries (samples Q3 and Q4, Fig. 9b) determined for sections normal to the $\mathrm{N}-\mathrm{S}$ vertical foliation plane and parallel to the L2 lineation are consistent with the sinistral sense of shear given by this shape fabric and other D2 shear criteria. C-axis fabrics are characterized by maxima close to the edge of the diagram and to the $\mathrm{Z}$-axis, indicating relatively low-temperature conditions $\left(300-350^{\circ} \mathrm{C}\right)$ during D2 (e.g. Nicolas and Poirier, 1976; Fueten, 1992; Law, 1990). This conclusion agrees with the fact that samples are located $5 \mathrm{~km}$ away from the syntectonic plutons and the MSZ. The poorly defined c-axis preferred orientation shown by sample Q3 is explained by its location within a zone where D2 was weak, in agreement with strain analysis section (see below).

\subsection{Quartz textures within granitoids}

Of the six diagrams of quartz c-axis fabrics produced for granodiorites (Fig. 9c), two come from the $\mathrm{E}-\mathrm{W}$ trending Barrocas complex (sample Q5 and Q6) and four come from the Ambrósio (samples Q7 and Q8) and Pedra Alta (samples Q9 and Q10) $\mathrm{N}-\mathrm{S}$ oriented plutons (locations in Fig. 10). The two diagrams made for the Barrocas complex (sample Q9 and Q10) confirm the dextral sense of shear inferred from the pervasive shear bands (Fig. 8). For the Ambrósio and Pedra Alta plutons, c-axis measurements have been made on samples selected from both the weakly oriented core and the mylonitic rim of each pluton. Within the core, c-axis figures show a maximum concentration close to the stretching lineation direction $\mathrm{X}$ (sample Q8 and Q10). Conversely, along the pluton margins (sample Q7 and Q9), maxima are located close to the $\mathrm{Z}$-axis. Kinematics inferred from fabric asymmetry is consistent with the D2 sinistral shearing.

C-axis preferred orientation obtained for granite margin samples suggest the activation of basal $\langle a\rangle$ glide system at low temperature because maxima are situated close to the diagram edge (Lister and Williams, 1979; Fueten, 1992). Conversely, the occurrence of c-axis maxima close to the $\mathrm{X}$ direction for samples collected within the core of the pluton can be interpreted as the result of the prismatic $\langle c\rangle$ slip activation at high temperature. However, as quartz occurs in the form of numerous and interstitial grains without evidence of internal deformation, it seems more justified to consider the crystallographic fabrics to have resulted from oriented grain growth rather than prismatic $\langle c\rangle$ glide (Tommasi et al., 1994). This process has been previously described within syntectonic granites (Gapais and Barbarin, 1986; Dell'Angelo and Tullis, 1988). The undeformed quartz microstructure in the core of the intrusion, drastically different from the dynamically recrystallized structure observed within pluton margins and surrounding supracrustal rocks, could thus be compared with 'pre-full crystallization' fabrics of Hutton (1988) (magmatic deformation developed in the presence of melt sufficient enough to minimize grain interaction). Indeed, pluton cores record high-temperature magmatic deformation whereas pluton margins were affected by low-temperature crystal plastic deformation due to the D2 leftlateral shearing.

The occurrence of one c-axis maxima located close to the stretching lineation (oriented grain growth) and another close to the foliation pole (low-temperature deformation) has been observed within sample Q7 (Fig. 9c), located along the Ambrósio pluton rim. This transition from relict magmatic and high-temperature fabrics to later low-temperature ones records the thermal evolution of the pluton during its deformation history and confirms that the plutons are syntectonic, deformed during a progressive decrease in temperature (Gapais and Barbarin, 1986; Gapais, 1989; Bouhallier et al., 1993). 


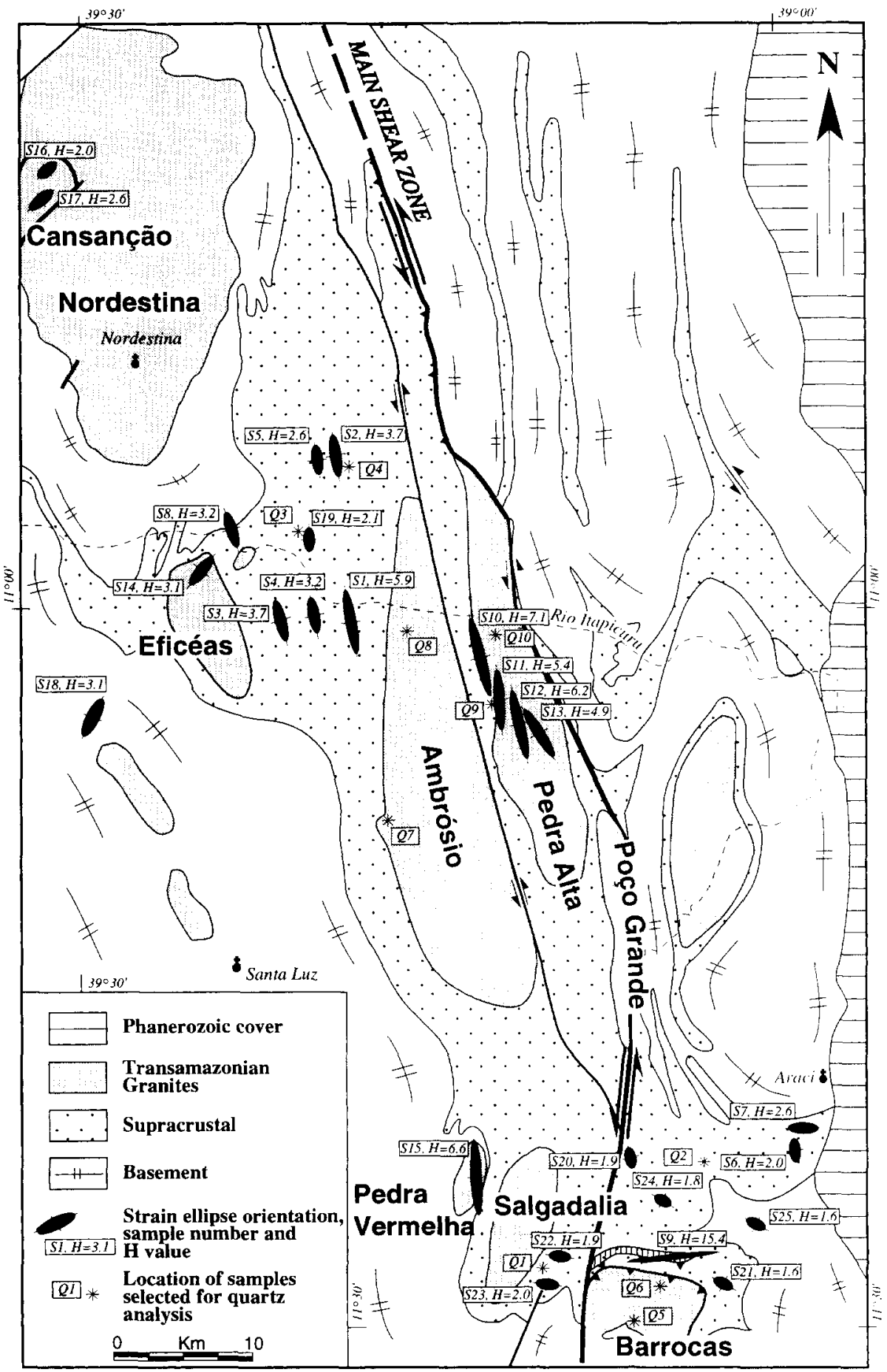

Fig. 10. Finite strain ellipse orientation ( XZ section, except for sample S6, YZ section) and harmonic mean $(H)$ plotted on a simplified map of the RIGB. Note the increasing finite strain values close to the MSZ (see details in Table 1). (Location of the samples selected for quartz $\mathrm{C}$-axis measurements is shown.) 


\section{Strain analysis}

\subsection{Procedure}

In the study area, strain markers include pillows in basalts flows, agglomerate clasts in supracrustal strata, and mafic enclaves and quartz phenocrysts within granitic and porphyritic rocks respectively. Strain measurements were performed in the field and in oriented hand-samples by measuring axial ratio $\left(R_{\mathrm{f}}\right)$ and pitch of the principal axes $(\phi)$ of elliptical markers within the $\mathrm{XZ}$ and $\mathrm{YZ}$ planes. A minimum of 30 measurements for each site is necessary to obtain reliable results. Methods of linear correlation of strain axes $(r)$ developed by Mukhopadhyaya (1973) have been applied to data from each station in order to verify if the markers could be considered to come from a single population with a certain axial ratio. The $R_{\mathrm{f}} / \phi$ method (Dunnet, 1969; Ramsay and Huber, 1983) was then used to obtain the values of $R_{\mathrm{s}}$ (finite strain) and $R_{\mathrm{i}}$ (initial shape) ratio. Finite strain has also been estimated using the harmonic mean value $(H$, Table 1) and fluctuation $F$ has been computed in order to validate the use of the $R_{\mathrm{f}} / \phi$ method which is considered inapplicable for $F$ values $<3$ (Hutton, 1979; Ramsay and Huber, 1983). We calculated the logarithmic variation of $R_{\mathrm{f}}$ (Hutton, 1979) for four stations selected in the supracrustal units in order to determine the possible effects of D2 overprinting upon D1.

\subsection{Results and interpretation}

Results of the strain analysis are summarized in Table 1 and depicted graphically in Fig. 10. Only results obtained on section $\mathrm{XZ}$ are represented (except for sample S6). They have been classified with respect to the different lithologies. For each analysed sample, the dip and strike of the stretching lineation, assumed to represent the longest axis of the finite strain ellipsoid (X), are also indicated. We describe the principal results below.

(1) The homogeneous nature and relatively high values (close to 1 ) of the linear correlation factor ( $r$, Table 1) indicate that the strain markers can be considered as initially random elliptical objects with similar axial ratios
(Mukhopadhyaya, 1973). This is confirmed by the quite homogeneous value of $R_{\mathrm{i}}$. Two supracrustal samples are characterized by lower $r$ value ca 0.8 . This reflects the existence of a preferred orientation before deformation or, as argued below, the existence of polyphase deformation (sample S1).

(2) Because the initial shape ratio $R_{\mathrm{i}}$ appears to be quite similar for all analysed samples, the variations of the finite strain ratio $R_{\mathrm{s}}$ are assumed to reflect changes in the intensity of the deformation. Finite strain $R_{\mathrm{s}}$ and harmonic mean $H$ are higher for the granitoids than for supracrustal and quartz-porphyric samples (Table 1). The large strain ratios obtained for the Pedra Alta and Pedra Vermelha plutons confirm the existence of the MSZ in the central RIGB (Fig. 10). Finite strain is relatively low within the supracrustals of the SE part of the RIGB. Only one agglomerate sample (S9), located within a shear zone, yields $R_{\mathrm{s}}$ and $H$ values close to 15 (Table 1 ). $R_{\mathrm{s}}$ is also low for the majority of the supracrustal samples located within the $\mathrm{N}-\mathrm{S}$ oriented part of the RIGB except for sample S1, located close to the Ambrósio intrusion.

(3) Additional measurements on section YZ, not listed in Table 1, have been obtained for four samples in order to apply the logarithmic variation method. The occurrence of two deformation stages has been demonstrated within sample S1 [illustrated by the difference between the logarithmic factors of $R_{\mathrm{i}}$ in section XZ and YZ, Table 1, see Hutton (1979) for explanation]. This may account for the low value of the linear correlation $r$ obtained for this sample $(0.842$, Table 1$)$. The existence of both D1 and D2 tectonic events within the northern domain is thus demonstrated. Sample S9, collected within a major shear zone, records the effects of an intense single phase deformational event attributed to D1. For two other samples collected far from the contact with the Ambrósio granite (S3 and S8), $R_{\mathrm{s}}$ values are similar to the typical values for the supracrustal rocks and thus do not contain evidence of polyphase tectonics. 
Table 1

Results of strain analysis

\begin{tabular}{|c|c|c|c|c|c|c|c|c|}
\hline Samples & $X$ & $R_{\mathrm{s}}$ & $R_{\mathrm{i}}$ & $H$ & $F$ & $r$ & $\log R_{i} \times z$ & $\log R_{i} y z$ \\
\hline \multicolumn{9}{|c|}{ Supracrustal rocks } \\
\hline S1 & $25 / 340$ & 6.9 & 1.7 & 5.90 & 10 & 0.842 & 0.23 & 0.36 \\
\hline S2 & $25 / 345$ & 3.7 & 1.8 & 3.68 & 21 & 0.955 & - & - \\
\hline S3 & $05 / 340$ & 4.3 & 2.1 & 3.70 & 46 & 0.839 & 0.32 & 0.29 \\
\hline S4 & $10 / 340$ & 3.1 & 1.3 & 3.20 & 10 & 0.990 & - & - \\
\hline S5 & $25 / 345$ & 2.7 & 2.4 & 2.65 & 58 & 0.916 & - & - \\
\hline$S 6^{*}$ & $15 / 088$ & 2.1 & 1.8 & 2.00 & 50 & 0.976 & - & - \\
\hline S7 & $05 / 090$ & 2.5 & 2.2 & 2.58 & 55 & 0.909 & - & - \\
\hline S8 & $25 / 340$ & 3.2 & 2.0 & 3.18 & 33 & 0.956 & 0.31 & 0.29 \\
\hline S9 & $15 / 080$ & 19.4 & 2.8 & 15.40 & - & - & 0.86 & 0.86 \\
\hline
\end{tabular}

\section{Granites}

Pedra Alta

S10

$\mathrm{S} 11$

S12

$\mathrm{S} 13$

Eficéas

S14

Pedra Vermelha

S15

Cansanção

S16

$\mathrm{S} 17$

$10 / 350$
$10 / 360$
$10 / 160$
$05 / 130$

\section{2}

5.3

7.0

5.1

$05 / 045 \quad 3.3$

$20 / 355 \quad 7.2$

\section{0}

\section{4}

2.3

2.3
3.2

7.07

5.40

6.22

4.88

20
7
8

0.829

0.993

0.949

0.949
0.865

1.8

$3.15 \quad 23$

0.975

$6.61 \quad 20$

0.803

$05 / 055 \quad 2.4$

2.8

$05 / 055$

3.0

$$
2.0
$$

2.04

49

0.914

2.58

0.956

\section{Basement}

\section{S18}

Quartz-porphyric rocks

S19
S20
S21
S22
S23
S24
S25

4.4

3.4

3.12

49

0.838

$\begin{array}{ll}20 / 360 & 2.6 \\ 15 / 160 & 1.2 \\ 05 / 120 & 1.8 \\ 25 / 110 & 2.2 \\ 30 / 095 & 1.8 \\ 05 / 120 & 1.7 \\ 05 / 120 & 1.5\end{array}$

$\begin{array}{ccc}2.10 & 52 & 0.930 \\ 1.90 & >90 & 0.983 \\ 1.58 & 48 & 0.966 \\ 1.90 & 45 & 0.957 \\ 2.00 & >90 & 0.924 \\ 1.80 & >90 & 0.942 \\ 1.60 & 180 & 0.950\end{array}$

For each sample, parameters shown are plunge of the stretching lineation $(X)$; finite strain ration $\left(R_{\mathrm{s}}\right)$; initial shape ratio $\left(\mathrm{R}_{\mathrm{i}}\right)$; harmonic mean value $(H)$; fluctuation $(F)$; linear correlation factor $(r)$. $\log R_{i} x z$ and $\log R_{i} y z$ have been calculated for samples $\mathrm{S} 1$, $\mathrm{S} 3, \mathrm{~S} 8$ and $\mathrm{S} 9$ in order to apply the logarithmic variation method. $r$ is calculated using $x_{i}$ and $z_{i}$ that are measured length of the elliptical marker following the $\mathrm{X}$ and $\mathrm{Z}$ direction, respectively (not listed herein). $H$ is calculated using the ellipticity $\left(R_{\mathrm{f}}\right)$ measured for each marker.

${ }^{*} \mathrm{YZ}$ section.

$F=\tan ^{-1} \frac{R_{\mathrm{s}}\left(R_{\mathrm{i}}^{2}-1\right)}{\left(\left(R_{i}^{2} R_{\mathrm{s}}^{2}-1\right)\left(R_{\mathrm{s}}^{2}-R_{i}^{2}\right)\right)^{1 / 2}}$

$H=\frac{n}{\left(R_{\mathrm{f} 1}^{-1}+R_{\mathrm{f} 2}^{-1}+R_{\mathrm{f} 3}^{-1} \ldots+R_{\mathrm{f} n}^{-1}\right)}$

$r=\frac{\sum_{i=1}^{i=n} x_{i} z_{i}}{\sqrt{\left(\sum_{i=1}^{i=n} x_{i}^{2}\right)\left(\sum_{i=1}^{i=n} z_{i}^{2}\right)}}$. 
(4) Seven samples of quartz-porphyric rocks were analysed (see localization in Fig. 10). Two of them provided from $\mathrm{N}-\mathrm{S}$ elongate bodies that were affected by the $\mathrm{N}-\mathrm{S}$ trending $\mathrm{D} 2$ sinistral shearing (sample S19 and S20). The five others come from the SE domain and were affected by $\mathrm{D} 1$ only. For all these samples, the $R_{\mathrm{s}}$ and $R_{\mathrm{i}}$ values are very close (Table 1 ) in spite of well-developed macroscopic structures (foliation and lineation). This, and the low axial ratio of quartz eyes, suggest that quartz eyes remained undeformed while phyllitic matrix suffered most of the deformation. Indeed, measurements within quartz-porphyries lead to an underestimate of the total amount of strain.

(5) In the Pedra Alta pluton, the decrease of the finite strain from the pluton margin towards the core is demonstrated by the diminution of the $R_{\mathrm{s}}$ value (sample $\mathrm{S} 10, \mathrm{~S} 11, \mathrm{~S} 12$ and $\mathrm{S} 13$ ). High strain along pluton margins reflects the combined effects of intrusion-related and tectonic-related deformation and confirms the syntectonic character of this pluton (Guglielmo, 1993).

\section{Structural evolution of the Rio Itapicuru greenstone belt}

\subsection{Main results}

The main results of the structural analysis of the RIGB are summarized below and integrated within a block diagram (Fig. 11).

- Two structural and metamorphic events, D1 and D2, are recognized both within metasedimentary and granitic rocks. The D1 event is best preserved in the southern part of the study area and involves top-to-SE shear. The D2 event is better developed and characterized by sinistral ductile shearing along NS-trending vertical foliation planes. Kinematic information deduced from quartz c-axis analyses are consistent with the results inferred from structural analysis.

- D1 and D2 deformations occur under quite similar greenschist/amphibolite facies PT conditions. However, quartz deformation was controlled by prism and basal $\langle a\rangle$ glide during D1 event whereas basal $\langle a\rangle$ glide characterized D2 thus suggesting that temperatures during D1 were slightly higher than during D2.

- Synkinematic granodioritic plutons were emplaced during the two tectonic events. The Barrocas pluton intruded coeval with D1 tectonics whereas others plutons and $\mathrm{N}-\mathrm{S}$ trending porphyries of the southern domain are contemporaneous with D2. This conclusion is consistent with available geochronological data. The syntectonic character of intrusion has been determined on the basis of microstructural arguments and quartz $\langle c\rangle$ axis fabrics. Quartz deformation mechanism evolves from high temperature oriented grain growth to low temperature basal $\langle a\rangle$ glide from the core to the rim of the N-S trending plutons, respectively. Contrasting quartz deformation processes between country rocks and granite support our proposal that the pluton were emplaced synkinematically (Gapais and Barbarin, 1986; Hutton, 1988).

- A MSZ is inferred from the following features: the elongated syntectonic plutons (Poço Grande and Pedra Alta), which record the higher strain values, are located along this zone;

D2 shearing is better developed within the Poço Grande and Pedra Alta intrusions than within other plutons, such as the Ambrósio and Salgadalia ones, where shear criteria are difficult to observe.

- Large-scale upright folds occur throughout the area. In the north, fold axes are oriented nearly $\mathrm{N}-\mathrm{S}$ whereas they are E-W to NE-SW and generally more open in the S-E (Fig. 11). Close to the MSZ, folds are tighter, in agreement with the higher strain values found in this area.

\subsection{Structural evolution}

\subsubsection{Nature and regional distribution of $D 1$ and D2 tectonic events}

The contact between supracrustal units and gneiss is not exposed so we could not determine whether the metasediments represent the cover to the gneisses, or if they tectonically overlie the 


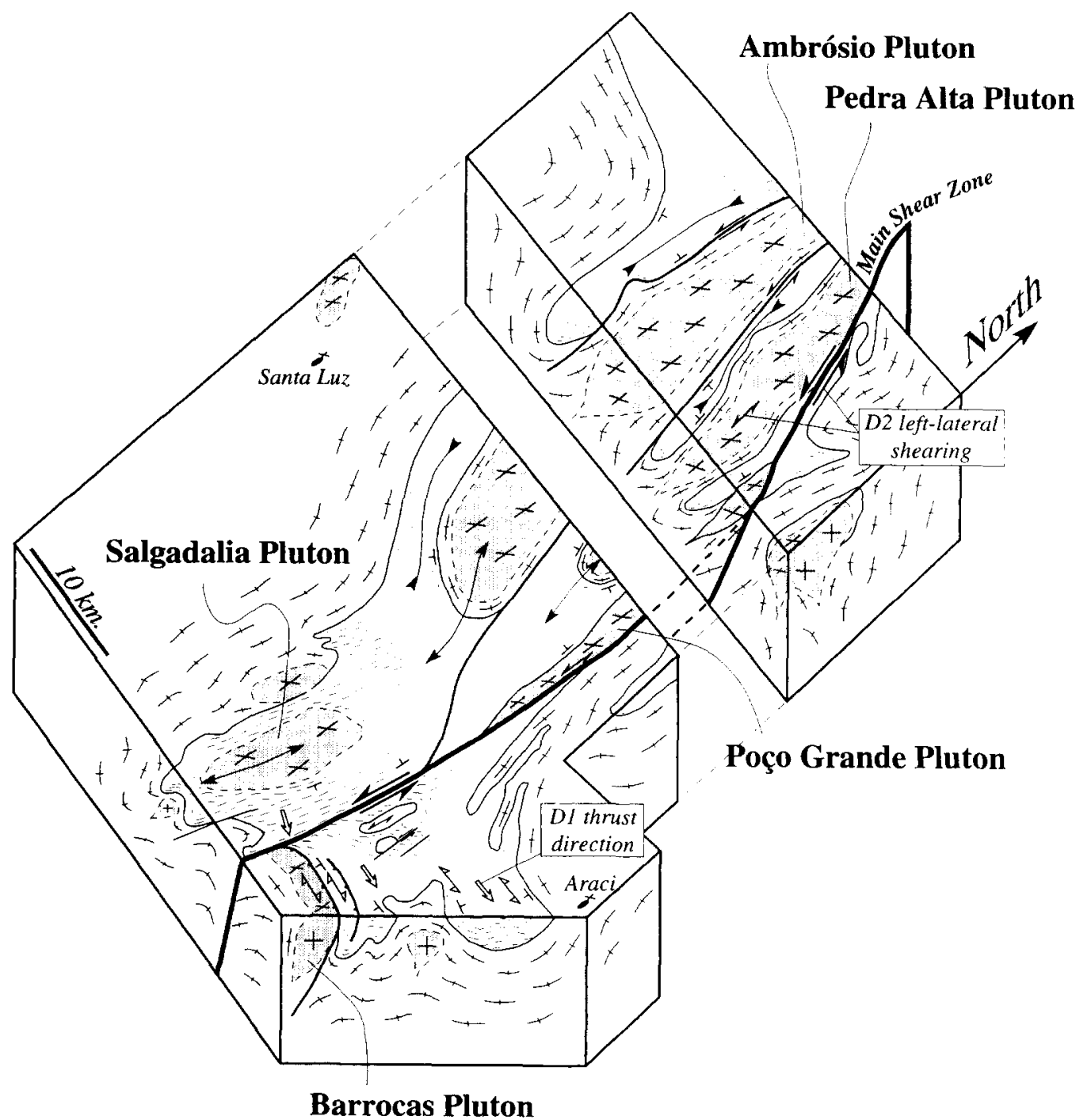

$\begin{array}{llll}++ & \text { Granite } & \text { D2 Ductile sense of shearing } \\ & \text { Quartz-porphyric rock } & \text { D1 Thrust direction and } \\ \text { associated sense of shearing }\end{array}$

Fig. 11. Block-diagram illustrating the main structures of the entire RIGB. 
gneisses. However, the development of D1 SE-verging tectonic lineations on a subhorizontal foliation suggests that the contact is tectonic. Thus, D1 tectonism involving thrust transport toward the SE caused the main foliation to form. Imbrications and intrafolial folds found in the metasediments (Alves da Silva, 1983; Teixeira, 1985; Teixeira et al., 1990; Kishida et al., 1991) could be correlated to this event. Although the D1 event is only observed within the southern domain, strain analysis demonstrates its existence within other domains of the RIGB. The D2 event is

a- Closure of the basin controlled by D1 SE-vergent thrusting. (ca. $2120 \mathrm{Ma}$ )
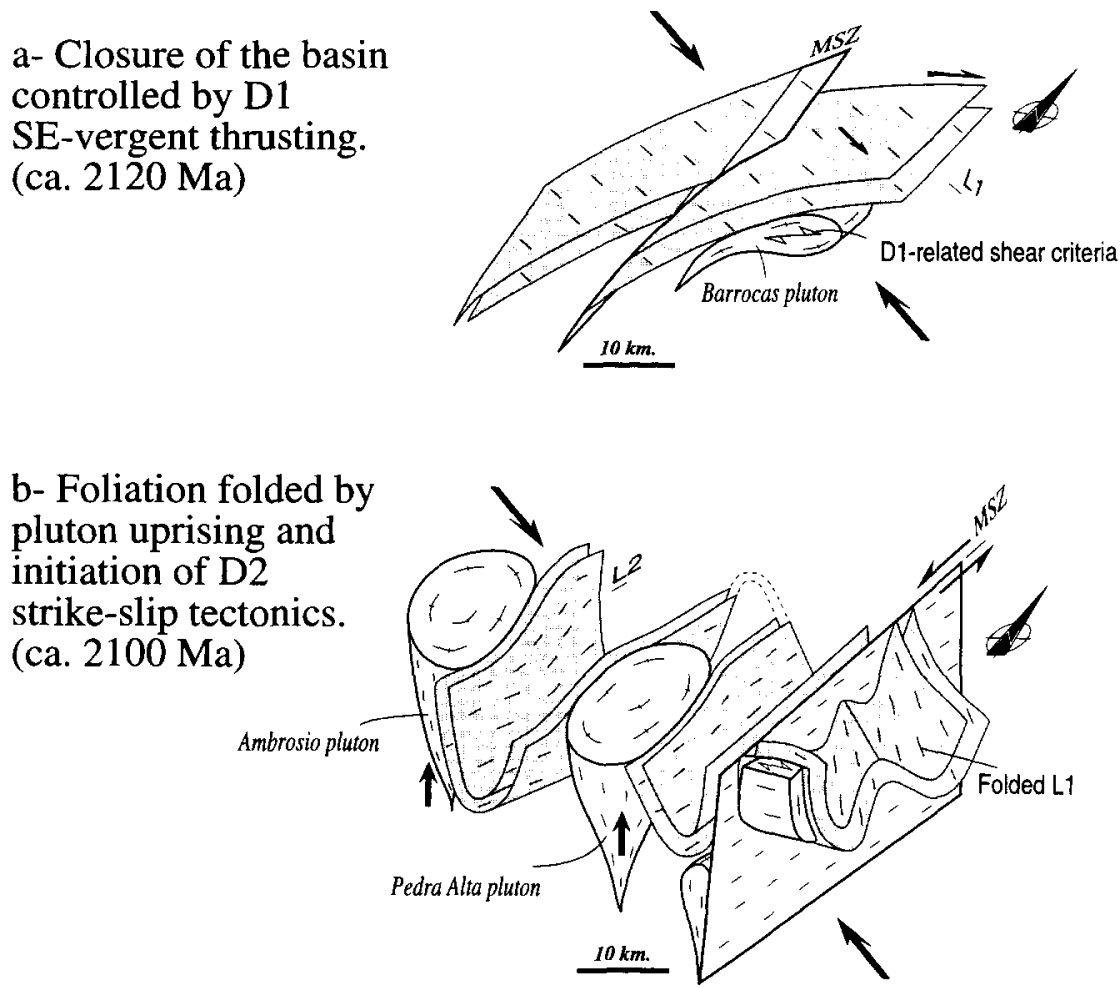

\section{c- Development of D2 tectonics both within metasediments and granites.}



Fig. 12. Schematic structural evolution of the RIGB showing the combination between horizontal tectonics (D1 event), left-lateral transcurrence (D2 event) and vertical emplacement of granites during NE-SW oriented shortening (see text for explanation). 
characterized by strike-slip tectonics particularly well-expressed within numerous synkinematic granites. It is worth noting that, within the southern RIGB, the D2 tectonic event has been recognized only within magmatic rocks such as $\mathrm{N}-\mathrm{S}$ trending quartz-porphyric intrusions and pegmatites (Figs. 4 and 5).

\subsubsection{Structural evolution and closure of the RIGB}

A tectonic model for the closure of the RIGB involving NW-SE directed contraction and integrating both $\mathrm{D} 1$ and $\mathrm{D} 2$ tectonics is herein proposed (Fig. 12). The closure of the basin was controlled by a west-dipping thrust zone located along the MSZ (Fig. 12a). During the first stages, and in response to a NW-SE oriented direction of contraction, D1 deformation yielded subhorizontal SE-verging thrusts within supracrustal units and created the main foliation. The first indication of plutonism is represented by the $2127 \mathrm{Ma}$-old Barrocas massif, which was emplaced during D1 and thus reflects the kinematics of this earlier event (Fig. 12a). Transcurrent D2 tectonics occurred ca 2100-2070 Ma, when most of the RIGB granitoids were emplaced. Granite ascent probably help the formation of kilometre-scale folds and the rotation of D1 foliation planes into steep dips (Fig. 12b). The NW-SE trending contraction acted upon subvertical $\mathrm{N}-\mathrm{S}$ trending foliation planes and induced the sinistral shearing, characteristic of the D2 event. The left-lateral ductile shearing is expressed within the N-S oriented syntectonic granites and is particularly well developed along the MSZ (Fig. 12c). At this time, the southern part of the RIGB is affected by large-scale E-W folds that reoriented D1-related structures (Fig. 12b). The formation of these folds could be related to the NNW-SSE shortening developed in response to the D2 left-lateral movement along the MSZ. North-directed thrusts developed along the northern border of the Barrocas pluton and within the Weber belt (Figs. 2b and 4) could be a result of the same process.

\subsection{Discussion and conclusion}

The Paleoproterozoic structural evolution of the RIGB involved a switch in tectonic style from
SE-verging thrusting (D1) to sinistral wrenching and granite emplacement (D2). The regional distribution of D1 and D2 events suggests that this change affected both sides of the MSZ, but D2 fabrics dominates west of the MSZ (northern domain) whereas D1 dominates to the SE (southern domain). Two alternative interpretations are suggested.

(1) The MSZ, marked by higher strain values, concentrated D2 deformation and localized the granite ascent thus explaining their emplacement along or close to this zone.

(2) Syn-D2 granites were mainly emplaced west of the MSZ enhancing the development of D2 strike-slip tectonics by straightening out the foliation during their ascent.

In this latter case, the absence of syn-D2 granites east of the MSZ could explain the lack of D2 tectonic fabrics there, except within small-size intrusive bodies. Several lines of arguments favour the second hypothesis. Within contemporary orogens, large-scale strike-slip tectonics is frequently related to post-collision lateral extrusion that accommodates the ongoing plate convergence when the maximal crustal thickness sustainable by the lithosphere is reached (e.g. Tapponnier et al., 1982; Peltzer and Tapponnier, 1988). Such an interpretation is unsatisfactory to explain the development of D2 event in the RIGB because evidence for significant crustal thickening and high-pressure metamorphism associated to D1 and D2 events are lacking. Indeed, it is suggested that granite emplacement and ascent, because they caused rotation of the $\mathrm{D} 1$ foliation into steep dips, could play a significant role in the development of the strike-slip tectonics.

\section{Acknowledgments}

F.C. Alves Da Silva research was supported by the Brazilian CNPq, process No. 200757/90.3. DOCEGEO and CVRD companies are particularly acknowledged for the logistic support in the field. Thanks are due to J.P. Burg, S. Hanmer and M.J. de Wit for comments on an earlier version of this manuscript. Additional comments and English corrections from S. Paterson improved the 
paper significantly and are much appreciated. R. Caby and S. Marshak provided useful and stimulating reviews for which we are grateful.

\section{References}

Alves da Silva, F.C., Matos, F.M.V., 1991. Economic geology and structural control of the orebodies from the Medium Itapicuru gold District. In: Ladeira, E.A. (Ed.), The Economic, Geology, Geochemistry and Genesis of Gold Deposits, Brazil Gold 91. Balkema, Rotterdam, pp. 629-635.

Alves da Silva, F.C., 1983. Geologia da Região de Mandacaru, Tucano, Bahia. Rel. Grad., Univ. Fed. RN, Natal, Brasil. $150 \mathrm{pp}$.

Alves da Silva, F.C., Chauvet, A., Faure, M., 1993. Early-Proterozoic Orogeny (Transamazonian) and syntectonic granite emplacement in the Rio Itapicuru greenstone belt, Bahia, Brazil. C. R. Acad. Sci. Paris, Sér. II 316, $1139-1146$

Alves da Silva, F.C., 1994. Etude structurale du "Greenstone belt" paléoprotérozoïque du Rio Itapicuru (Bahia, Brésil). Unpubl. thesis, Univ. Orléans, $340 \mathrm{pp}$.

Bertrand, J.M., Jardim de Sá, E.F., 1990. Where are the Eburnian-Transamazonian collisional belts? Can. J. Earth Sci. 27, 1382-1393.

Bouhallier, H., Choukroune, P., Ballèvre, M., 1993. Diapirism bulk homogeneous shortening and transcurrent shearing in the Archaean Dharwar craton: the Holenarsipur area, southern India. Precambrian Res. 63, 43-58.

Brito Neves, B.B., Cordani, U.G., Torquato, R.J., 1980. Evolução geocronológica do Precambriano do estado da Bahia. Textos Básicos-Ba, SME/CPM 3, 1-101.

Brun, J.P., Pons, J., 1981. Strain patterns of pluton emplacement in a crust undergoing non-coaxial deformation, Sierra Morena, Spain. J. Struct. Geol. 3, 219-229.

Chauvet, A., Faure, M., Dossin, I., Charvet, J., 1994. A three stage structural evolution of the Quadrilatéro Ferrifero: consequences for the Neoproterozoic age and the formation of gold concentration of the Ouro Preto area, Minas Gerais, Brazil. Precambrian Res. 68, 139-167.

Chauvet, A., Guerrot, C., Alves da Silva, F.C., Faure, M., Géochronologie ${ }^{207} \mathrm{~Pb} /{ }^{206} \mathrm{~Pb}$ et ${ }^{40} \mathrm{Ar} /{ }^{39} \mathrm{Ar}$ des granites paléoprotérozoïques de la ceinture de roches vertes du Rio Itapicuru (Bahia Brésil). 1997. C. R. Acad. Sci. Paris II 324, 293-300.

Clemens, J.D., Mawer, C.K., 1992. Granitic magma transport by fracture propagation. Tectonophysics 204, 339-360.

Davison, I., Teixeira, J.B.G., Silva, M.G., Neto, M.B.R., Matos, F.M.V., 1988. The Rio Itapicuru Greenstone Belt, Bahia, Brazil: structure and stratigraphical outline. Precambrian Res. 42, 1-17.

de Wit, M.J., Roering, C., Hart, R.J., Armstrong, A., de Ronde, C.E.J., Green, R.W.E., Tredoux, M., Peberdy, E., Hart, R.A., 1992. Formation of an Archaean continent. Nature 357, 553-562.
Dell'Angelo, L.N., Tullis, J., 1988. Experimental deformation of partially melted granite aggregates. J. Metamorph. Geol. $6,495-515$.

Dixon, J.M., 1975. Finite strain and progressive deformation in models of diapiric structures. Tectonophysics $28,89-124$.

Dunnet, D., 1969. A technical of finite strain analysis using elliptical particles. Tectonophysics 7, 117-136.

England, R.W., 1990. The identification of granite diapirs. J. Geol. Soc., Lond. 147, 931-933.

Fueten, F., 1992. Tectonic interpretation of systematic variation in quartz c-axis fabrics across the Thompson belt. J. Struct. Geol. 14, 775-789.

Gaál, G., Teixeira, J.B.G., Del Rei Silva, J.L.H., Silva, M.G., 1987. Early Proterozoic evolution and metallogenesis in Northwestern Bahia-Brazil. International Symposium on Granite and Metallogenesis (ISGAN), Salvador-Bahia.

Gapais, D., 1989. Shear structures within deformed granites: mechanical and thermal indicators. Geology 17, 1144-1147.

Gapais, D., Barbarin, B., 1986. Quartz fabric transition in a cooling syntectonic granite (Hermitage Massif, France). Tectonophysics $125,357-370$.

Guglielmo, G., Jr., 1993. Interference between pluton expansion and non-coaxial tectonic deformation: three dimensional computer model and field implications. J. Struct. Geol. 15, 593-608

Hanmer, S., Bowring, S., Van Breemen, O., Parrish, R., 1992. Great Slave-Lake shear zone, NW Canada: mylonitic record of Early Proterozoic continental convergence, collision and indentation. J. Struct. Geol. 14, 757-773.

Hutton, D.H.W., 1979. The strain history of a Dalradian slide using pebbles with low fluctuation in axis orientation. Tectonophysics 55, 261-273.

Hutton, D.H.W., 1988. Granite emplacement mechanisms and tectonic control: inferences from deformation studies. Trans. R. Soc. Edinburgh 79, 245-255.

Jelsma, H.A., Van der Beek, P.A., Vinyu, M.L., 1993. Tectonic evolution of the Bidura-Shamwa greenstone belt (northern Zimbabwe): progressive deformation around diapiric batholiths. J. Struct. Geol. 15, 163-176.

Kishida, A., Sena, F.O., Alves da Silva, F.C., 1991. Rio Itapicuru greenstone belt: geology and gold mineralization. In: Ladeira, E.A. (Ed.), The Economic, Geology, Geochemistry and Genesis of Gold Deposits, Brazil Gold 91. Balkema, Rotterdam, pp. 49-59.

Kishida, A., Riccio, L., 1980. Chemostratigraphy of lava sequences from the Rio Itapicuru greenstone belt, Bahia, Brazil. Precambrian Res. 11, 161-178.

Lamarck Argolo, J., Debat, P., Driouch, Y., Lelubre, M., Roux, L., 1994. Evolution archéenne et protérozoïque inférieur de la partie nord-orientale du craton de São Francisco (région de Valente-Santa Luz Bahia, Brésil). Bull. Soc. Géol. Fr. $165,531-540$.

Law, R.D., 1987. Heterogeneous deformation and quartz crystallographic fabric transitions: natural examples from the Moine Thrust zone at the Stack of Glencoul, northern Assynt. J. Struct. Geol. 9, 819-833.

Law, R.D., 1990. Crystallographic fabrics: a selective review 
of their applications to research in structural geology. In: Knipe, R.J., Rutter, E.H. (Eds.), Deformation Mechanisms, Rheology and Tectonics. Geological Society Special Publication. Geological Society, London, Vol. 54, pp. 335-352.

Ledru, P., Pons, J., Milesi, J.P., Feybesse, J.L., Johan, V., 1991. Transcurrent tectonics and polycyclic evolution in the Lower Proterozoic of Senegal-Mali. Precambrian Res. 50, 337-354.

Lister, G.S., Williams, P.F., 1979. Fabric development in shear zones, theoretical controls and observed phenomena. J. Struct. Greol. 1, 283-297.

Lucas, S.B., 1989. Structural evolution of the Cape Smith Thrust Belt and the role of out-of-sequence faulting in the thickening of mountain belt. Tectonics 8, 655-676.

Marshak, S., Alkmim, F.F., 1989. Proterozoic contraction/ extension tectonics of the southern São Francisco region, Minas Gerais, Brazil. Tectonics 8, 555-571.

Marshak, S., Alkmim, F.F., Jordt-Evangelista, H., 1992. Proterozoic crustal extension and the generation of domeand-keel structure in an Archaean granite-greenstone terrane. Nature 357, 491-493.

Mascarenhas, J.F., 1976. Geologia da regiâo centro oriental da Bahia: projeto Bahia II, Sul da Bahia. ConvÉnio DNPM/CPRM, Salvador, Relatório final, Vol. 1.

Matos, F.M.V., Davison, I., 1987. Basement or intrusion? The Ambrósio dome, Rio Itapicuru Greenstone Belt, Bahia, Brazil. Rev. Bras. Geoc. 17, 442-449.

Mukhopadhyaya, D., 1973. Strain measures from deformed quartz grains in the slaty rocks from the Ardennes and the Northern Eifel. Tectonophysics 16, 279-296.

Nicolas, A., Poirier, J.P., 1976. Crystalline Plasticity and Solid State Flow in Metamorphic Belts. Wiley, London.

Paterson, S.R., Vernon, R.H., Tobisch, O.T., 1989. A review of the identification of magmatic and tectonic foliations in granitoids. J. Struct. Geol. 11, 349-363.

Peltzer, G., Tapponnier, P., 1988. Formation and evolution of strike-slip faults, rift and basins during the India-Asia collision: an experimental approach. J. Geophys. Res. 93, 15085-15117.

Platt, J.P., 1980. Archaean greenstone belts: a structural test of tectonic hypothesis. Tectonophysics $65,127-150$.

Pons, J., Barbey, P., Dupuis, D., Léger, J.M., 1995. Mechanisms of pluton emplacement and structural evolution of a $2.1 \mathrm{Ga}$ juvenile continental crust: the Birimian of southwestern Niger. Precambrian Res. 70, 281-301.

Ramberg, H., 1981. Gravity, Deformation of the Earth's Crust in Theory, Experiments and Geological Application. Academic Press, London.
Ramsay, J.G., 1989. Emplacement kinematics of a granite diapir: the Chindamora batholith, Zimbabwe. J. Struct. Geol. 11, 191-202.

Ramsay, J.G., Huber, M.I., 1983. The Technics of Modern Structural Geology, Vol. I: Strain Analysis. Academic Press, London.

Reinhardt, M.C., Davison, I., 1990. Structural and lithological controls on gold deposition in the shear zone-hosted Fazenda Brasileiro mine, Bahia state, Northeast Brazil. Econ. Geol. 85, 952-967.

Sabaté, P., Marinho, M.M., Vidal, Ph., Vachette, M.C., 1990. The $2 \mathrm{Ga}$ peraluminous magmatism of the Jacobina-Contendas Mirante belts (Bahia, Brazil): geologic and isotopic constraints on the sources. Chem. Geol. 83 , 325-338.

Shackleton, R.M., 1986. Precambrian collision tectonics in Africa. In: Coward, M.P., Ries, A.C. (Eds.), Collision Tectonics, Geological Society Special Publication. Geological Society, London, Vol. 19, pp. 329-349.

Silva, M.G., 1987. Geochemie, Petrologie and geotektonische entwicklung eins Proterozoischen greunsteignertels, Rio Itapicuru, Bahia, Brasilien. Unpubl. Ph.D. Thesis, Univ. Freiburg, Germany.

Silva, M.G., 1992. Evidências isotopicas e geocronologicas de um fenômeno de acrescimento crustal Transamazônico no craton São Francisco, estado da Bahia. 37th Congr. Bras. Geol. SBG, São Paulo, anais II, pp. 181-182.

Silva, M.G., Vidal, Ph., 1992. Evidences of an arc-continent collision in the NE portion of the São Francisco Craton. 14ème Réun. Sci. Terre, Toulouse, France, p. 69.

Tapponnier, P., Peltzer, G., Le Dain, A.Y., Armijo, R., Cobbold, P., 1982. Propagating extrusion tectonics in Asia: new insights from simple experiments with plasticine. Geology 10, 611-616.

Teixeira, J.B.G., 1985. Geologia e controle da mineralização aurifera em Fazenda Brasileiro, Serrinha, Bahia. Geol. Recur. Miner. da Bahia, Textos Básicos 6, 9-49.

Teixeira, J.B.G., Kishida, A., Marimon, P.M.C., Xavier, R.P., MacReath, I., 1990. The Fazenda Brasileiro gold deposit, Bahia: geology, hydrothermal alteration and fluid inclusion studies. Econ. Geol. 85, 990-1009.

Teixeira, W., Figueiredo, M.C.H., 1991. An outline of the Early Proterozoic crustal evolution in the São Francisco Craton. Precambrian Res. 53, 1-22.

Tommasi, A., Vauchez, A., Fernandes, L.A.D., Porcher, C.C., 1994. Magma-assisted strain localization in an orogenparallel transcurrent shear zone of southern Brazil. Tectonics $13,421-437$. 